\title{
Indexação de xilogravuras de cordel: uma abordagem sob a pers- pectiva cognitiva
}

\author{
Indexing cordel xilogravures: an approach under the cognitive perspective \\ Raimunda Fernanda dos Santos \\ Doutora em Ciência da Informação \\ Universidade Federal do Rio de Janeiro \\ nandaflorania@gmail.com
}

\author{
Maria Elizabeth Baltar Carneiro de Albuquerque \\ Doutora em Ciência da Informação \\ Universidade Federal da Paraíba \\ ebaltar2007@gmail.com
}

Dulce Amélia de Brito Neves

Doutora em Ciência da Informação Universidade Federal da Paraíba damelia1@gmail.com

\section{Resumo}

Estuda aspectos relativos à indexação, operação que visa extrair o conteúdo dos objetos informacionais para fins de sua recuperação, acesso e uso. Objetiva identificar os aspectos cognitivos inerentes à atividade de indexação de xilogravuras de capas de folhetos de cordel efetuada por profissionais da informação. Utiliza como metodologia a pesquisa bibliográfica para a fundamentação teórica do assunto estudado, seguida de um delineamento de caráter exploratório e descritivo com um estudo de caso contemplando um grupo experimental de sujeitos indexadores que trabalham em unidades de informação que possuem acervos de cordel para fins de aplicação de um questionário e da técnica de protocolo verbal individual cuja inspeção dos dados obtidos foi efetuada por meio da técnica de análise de conteúdo. Constata que, através dos processos cognitivos, as participantes da pesquisa desenvolveram estratégias que viabilizam a atividade de indexação das xilogravuras, analisando e identificando os elementos presentes nas imagens e os seus respectivos referentes. Porém, como subsídio informacional foram consultados os títulos e os versos dos próprios folhetos cujas xilogravuras estavam sendo representadas. Conclui que a complexidade inerente à atividade de indexação de imagens como as xilogravuras não está apenas associada ao fato da necessidade e compreensão do profissional da informação acerca de um conceito contido em recursos não textuais, faz-se necessário que esse profissional identifique a maneira como os conceitos estão sendo apropriados pelos usuários, uma vez que essas imagens retratam o imaginário e a cultura popular.

\section{Palavras-chave}

Informação imagética. Indexação de imagens - metacognição. Xilogravuras de cordel.

\section{Abstract}

Studies aspects related to indexing, an operation that aims to extract the contents of informational objects for retrieval, access and use. It aims to identify the cognitive aspects inherent to the indexing activity of woodcuts from woodcuts made by information professionals. It uses as a methodology the bibliographic research for the theoretical basis of the studied subject, followed by an exploratory and 
descriptive design with a case study contemplating an experimental group of indexing subjects who work in information units that have collections of string for application purposes of a questionnaire and of the technique of individual verbal protocol whose inspection of the obtained data was done through the technique of content analysis. It observes that, through the cognitive processes, the research participants developed strategies that enable the indexing activity of woodcuts, analyzing and identifying the elements present in the images and their respective referents. However, as an informational subsidy, the titles and verses of the own leaflets whose woodcuts were being represented were consulted. It concludes that the complexity inherent to the activity of indexing images such as woodcuts is not only associated with the fact that the information professional needs and understands a concept contained in non-textual resources, it is necessary that the professional identify the way concepts are being appropriated by users, since these images portray the imaginary and the popular culture.

\section{Keywords}

Imaging information. Indexing of images - metacognition. Cordel woodcuts.

\section{INTRODUÇÃO}

A Ciência da Informação consiste em um campo interdisciplinar que se preocupa, principalmente, em tornar a informação acessível para aqueles que dela necessitam, tendo em vista que os itens informacionais, independente do seu formato ${ }^{1}$ (áudio, texto, imagem, vídeo, etc.), devem passar por um conjunto de tarefas de armazenamento, organização e representação para que seja possível a sua recuperação, acesso e uso em sistemas de recuperação da informação.

Nessa perspectiva, esses itens devem ser tratados levando em consideração tanto as operações que contemplam a sua descrição física, como também a descrição do seu conteúdo para fins de acesso e uso.

A indexação se configura como uma atividade integrante do tratamento temático da informação, que visa descrever os conteúdos dos itens informacionais por meio de termos provenientes de linguagens documentárias para fins de disponibilização das informações pertinentes às necessidades dos usuários (FUJITA, 2003). Desse modo, a indexação condiciona os resultados de uma estratégia de busca e a qualidade dessa atividade reflete na recuperação, no acesso e no uso da informação pela geração hodierna e futura.

Com isso, verifica-se a imprescindibilidade do compromisso do indexador na execução dessa tarefa, tendo em vista que a indexação consiste em uma atividade intelectual considerada como o limite dos aparelhos tecnológicos, uma vez que o computador, por exemplo, ainda não realiza o trabalho humano de abstrair, distinguir, compreender e assimilar o que está presente nos itens informacionais (SANTOS, 2016). Nesse entendimento, todas as fases do processo de indexação sofrem influências de fatores linguísticos, cognitivos, lógicos, contextuais e culturais, simultaneamente.

Esses fatores citados podem adquirir um grau de complexidade ainda maior quando aplicados ao contexto da informação imagética. Os recursos imagéticos, em especial as xilogravuras, objeto do presente estudo, apresentam informações que precisam ser analisadas para serem recuperadas e acessadas por artistas, pesquisadores, colecionadores de arte e usuários em geral. Isso se deve ao fato de que o artista encontra na xilogravura um modo de transmitir suas manifestações, tornando-a uma fonte inesgotável da alma popular, procu-

\footnotetext{
1 Nesta pesquisa, o conceito de formato está relacionado à configuração física, forma dos objetos
} informacionais. 
rando humanizar bichos, demônios e todas as demais figuras reais ou irreais que a sua prodigiosa imaginação vislumbra (CARVALHO, 2014).

Merece ainda uma atenção especial o tratamento temático das xilogravuras cujas ilustrações expressivas trazem consigo a originalidade dos xilógrafos e são inspiradas na poesia. Dessa forma, corroboramos com Rodrigues Filho (2016, p.662) quando ressalta que as xilogravuras são recursos imagéticos que possuem o poder de apresentar diferentes significações, "evocando em seus leitores as mais diversas acepções e memórias".

Para tanto, surge o seguinte questionamento: Quais as estratégias metacognitivas de leitura são usadas pelos indexadores durante a análise de xilogravuras de capas de folhetos de cordel para fins de representação do seu conteúdo?

No intuito de responder essa indagação, a presente pesquisa tem como objetivo geral identificar os aspectos cognitivos inerentes à atividade de indexação de xilogravuras de capas de folhetos de cordel efetuada por profissionais da informação.

A relevância desta investigação decorre da necessidade de estudar questões concernentes ao tratamento da informação imagética, em especial xilogravuras, sob o viés da Organização e Representação do Conhecimento. Além disso, verifica-se a necessidade de analisar o indexador como um leitor que, ao desempenhar uma atividade puramente intelectual e subjetiva de representar o conteúdo de xilogravuras através de suas posições de leitura, busca tornar a informação acessível para aqueles que dele necessitam.

\section{AS PRÁTICAS DE REPRESENTAÇÃO TEMÁTICA DA INFORMAÇÃO E O PROFISSIONAL INDEXADOR}

De acordo com Fujita (2003), a indexação consiste em uma atividade puramente intelectual que objetiva representar os conteúdos dos itens informacionais, de maneira concisa e condensada, por meio de termos para fins de sua representação e recuperação.

Esses termos são atribuídos pelo indexador e configuram como, ou se propõem a ser, pontos de acesso mediante os quais os materiais informacionais podem ser identificados, recuperados, acessados e utilizados. Destarte, corroboramos com Lucas (1997, p. 49) quando essa autora ressalta que a indexação "[...] encaminha o leitor por vários percursos, enriquece ou confunde os possíveis olhares que serão lançados à obra", tendo em vista que o olhar leitor do profissional silencia ou expõe diferentes leituras.

Nesse segmento, verifica-se a complexidade do trabalho do indexador, responsável pela realização do tratamento temático dos itens informacionais, cuja atividade está metodologicamente associada a duas etapas intelectualmente distintas: a análise de assunto, também denominada de análise conceitual, que diz respeito à extração de conceitos que representam o conteúdo de um item informacional, e a sua tradução para uma linguagem atinente ao sistema. A etapa da tradução, por sua vez, consiste na representação dos documentos em termos provenientes de instrumentos de indexação, os quais são denominados de linguagens de indexação ou linguagens documentárias como as Listas de Cabeçalhos de Assunto, os Tesauros ${ }^{2}$ e as Ontologias ${ }^{3}$ (NAVES, 2001).

\footnotetext{
2 Os Tesauros são linguagens documentárias que contemplam domínios específicos do conhecimento apresentando alta exatidão terminológica e de relações (hierárquicas, não hierárquicas e de equivalência) entre os conceitos no intuito de representar e recuperar os itens informacionais em sistemas.

3 “Ontologias são instrumentos de indexação que apresentam uma estrutura de termos e as relações entre eles na perspectiva do sujeito e da linguagem de um determinado domínio. Apresentam-se como alternativas viáveis para organizar o conhecimento em ambiente Web na forma de uma teia de relações permitindo a ligação entre os conceitos." (SANTOS, 2016, p. 24).
} 
Contudo, não se pode definir o assunto de um recurso informacional sem que sejam considerados diversos aspectos, além do contexto em que ele está inserido. Corrobora-se com Lucas (1997) quando a mesma destaca que a leitura do indexador não é resumida aos procedimentos e técnicas de tratamento dos recursos informacionais. Sendo assim, nas práticas de indexação realizadas pelos indexadores é possível observar e levar também em consideração os gestos de leitura desses sujeitos, enquanto leitores, os quais são inerentes à sua formação discursiva configurada em processos de significação. Nessa perspectiva, essa representação é feita a partir da interpretação e viabiliza o encontro de posições de leitura que constituem diferentes lugares de construção de sentido, dentre eles a do indexador na qualidade de leitor da informação.

Esses fatores adquirem um grau de complexidade ainda maior quando aplicados ao contexto da análise dos recursos imagéticos, os quais possuem característica polissêmica diante da sua capacidade de produzir diferentes significados - tanto na perspectiva dos indexadores quanto na perspectiva dos seus usuários; uma vez que cada sujeito pode construir a sua unidade de sentido e cada sentido é proveniente da cognição, memória e percepção do mundo.

Apesar de existirem metodologias voltadas especificamente para a representação temática de imagens, observa-se que as questões concernentes a essa operação com enfoque na perspectiva cognitiva e metodológica ainda precisam ser exploradas, principalmente no contexto da indexação de xilogravuras de cordel, haja vista a inexistência de metodologias e políticas de indexação que contemplem as especificidades desses recursos imagéticos.

\section{ANÁLISE DA INFORMAÇÃO IMAGÉTICA: ASPECTOS COGNITIVOS}

A análise da informação diz respeito à operação que agrega um conjunto de práticas que viabilizam a compreensão, descrição, representação e organização dos conteúdos de itens informacionais através do uso de técnicas e procedimentos provenientes dos estudos e investigações da área de Ciência da Informação, objetivando a recuperação, o acesso e o uso da informação, independentemente do seu suporte.

Segundo Maia e Albuquerque (2014), a análise da informação é composta por três dimensões: conceitual, estratégica e operacional. Para essas autoras, a dimensão conceitual está relacionada à primeira ação de reflexão do indexador acerca do conteúdo do item informacional e a extração de conceitos que o representem de maneira concisa e condensada. De outro modo disposto, a dimensão estratégica envolve aspectos relativos à política de indexação e às estratégias dotadas que norteiam a realização dessa atividade. Por outro lado, a dimensão operacional está associada à prática de representação dos aspectos físicos e temáticos dos recursos informacionais. Nessa última dimensão, percebe-se que a atividade de indexação envolve interpretações, escolhas e controle terminológico para fins de representação.

Diante disso, observa-se que o processo cognitivo está intimamente integrado à análise da informação. No que concerne à cognição, Mussen et al. (1988, p. 210) enfatizam que:

[...] é um conceito amplo e abrangente que se refere às atividades mentais envolvidas na aquisição, processamento, organização e uso do conhecimento. Os processos principais envolvidos no termo cognição incluem detectar, interpretar, classificar e recordar informação; avaliar ideias; inferir princípios e deduzir regras; imaginar possibilidades; gerar estratégias, fantasiar e sonhar. 
Com base nessa perspectiva, é possível identificar que a cognição está relacionada à mente humana e aos seus processos. Para Gonçalves, Oliveira e Neves (2016, p. 113), esses processos se manifestam como "um conjunto de fenômenos psicológicos que surgem na mente devido à influência de fatores internos e externos ao indivíduo". Os fenômenos psicológicos, por sua vez, atuam como mecanismos de aprendizagem e podem ser denominados de processos cognitivos. Ainda de acordo com esses autores, a representação temática é uma atividade que se configura como fruto de uma capacidade cognitiva resultante da reflexão do uso da linguagem verbal ou não verbal e de sinais não linguísticos, como por exemplo, as imagens.

Neves (2006) ressalta que a cognição está diretamente associada às atividades de processamento técnico e recuperação da informação dos itens informacionais efetuadas pelos profissionais da informação. Isso se deve ao fato de que tais operações envolvem percepção ${ }^{4}$, memória ${ }^{5}$, inferência e dedução. Já a metacognição é "conhecimento sobre o próprio conhecimento, avaliação, regulação e organização dos processos cognitivos" (NEVES, 2011, p. 29). Assim sendo, essa última está relacionada à avaliação realizada pelo sujeito em relação ao seu conhecimento, ou seja, ao que se sabe.

Diante do exposto, observa-se que os aspectos associados à mente humana são complexos e interferem, por exemplo, na maneira como um sujeito realiza a análise de um recurso imagético, o que exige a necessidade de métodos específicos para a indexação desses recursos, haja vista a sua capacidade de gerar diversas significações. Pois o indexador pode destacar os significados da imagem que mais lhe interessam, no momento da indexação, e que foram provenientes de sua percepção, podendo não necessariamente satisfazer as necessidades dos usuários.

Segundo Manini (2002, p. 73), o conteúdo intelectual que uma imagem pode vir a representar diz respeito a "[...] tudo aquilo que não é a imagem em si, embora ele 'esteja' na imagem". Todavia, corroboramos com Gonçalves, Oliveira e Neves (2016) quando afirmam que é uma tarefa difícil estabelecer os elementos presentes ou ausentes em uma imagem, baseando-se no que ela venha a transmitir para o usuário, o que pode resultar em uma variedade de interpretações, análises e descritores relativos.

No que diz respeito às contribuições de pesquisas voltadas para a análise da informação imagética, Panofsky (1977), crítico e historiador de arte, criou a teoria da análise iconológica cujo método busca compreender uma obra através de três níveis de análise, são eles: pré-iconográfico, iconográfico e iconológico. O nível pré-iconográfico centra-se na descrição genérica dos objetos e ações representadas pela imagem. De outro modo disposto, o nível iconográfico visa a identificação dos assuntos secundários ou convencionais da imagem mediante a identificação dos significados simbólicos, mítico ou abstrato da imagem, os quais são provenientes dos elementos detectados pela análise pré-iconográfica. O nível iconológico, por sua vez, está voltado para a interpretação do significado intrínseco do conteúdo da imagem por meio das análises realizadas nos níveis anteriores e da inserção de conhecimentos específicos sobre o ambiente cultural, artístico e social no qual a imagem foi criada.

\footnotetext{
${ }^{4}$ Capacidade que a mente tem de atribuir significados aos estímulos captados por meio dos sentidos (GONÇALVES; OLIVEIRA; NEVES, 2016).

${ }^{5} \mathrm{O}$ conceito de memória é amplo e é empregado em diversas áreas do conhecimento. Entretanto, quando esse conceito está direcionado à abordagem cognitiva, o mesmo relaciona-se à capacidade de aquisição, armazenamento e recuperação (quando necessário) de informações no cérebro. (GONÇALVES; OLIVEIRA; NEVES, 2016).
} 
Essa teoria serviu como base para a construção de diferentes metodologias de representação de imagens apresentadas por diversos autores, dentre eles Shatford (1984), Smit (1987) e Manini (2002). Essas metodologias não são descritas ou aplicadas no presente estudo, uma vez que essa tarefa não se constitui como objetivo da pesquisa em questão. O foco é investigar, sob o viés das estratégias metacognitivas, aspectos relativos à indexação de xilogravuras.

Em síntese, para Gonçalves, Oliveira e Neves (2016), a análise da informação imagética resulta na triangulação entre o referente, a capacidade imaginativa do indivíduo e a sua interpretação. Na concepção dos autores, a imagem se configura como um registro do fragmento de um mundo visível. Nessa perspectiva, o referente é o elemento central da imagem, o qual é constituído pelo olhar e enquadramento do autor e evidencia um foco cujas análises efetuadas por diferentes pessoas são alvo de diferentes interpretações. Entretanto, destaca-se que a representação simbólica relacionada à imagem e que não se encontra visível, de forma objetiva na mesma, também suscita diversas interpretações inerentes à nossa capacidade imaginativa enquanto representação mental.

Segundo Oliveira (2013, p. 118), o conteúdo informacional de um recurso imagético pode ser caracterizado como "o que a imagem mostra", ou seja, o seu referente está intimamente ligado à constituição de sentido. Para esse autor, cada indivíduo pode construir a sua unidade de sentido e cada sentido é proveniente do contexto cultural, social de percepção.

Oliveira (2014, p. 16) explica sobre o significado da informação no contexto das imagens:

Informação como um objeto de significação, de produção de sentidos, de representação. Informação é signo. Ela existe e é ressignificada. Dessa forma, nas imagens, a informação é algo que gera um significado, representa (chega a confundir-se com o próprio objeto representado), da vazão à construção de novas ideias, leituras e interpretações. A informação enquanto objeto, um elemento, um evento de sensações e percepções. [...] Informação em imagens é polissêmica e polifônica.

Baseando-se na ideia desse autor, a informação vinculada às imagens é denominada de informação imagética. De acordo com Rodrigues (2007, p. 2007), tais informações só podem ser identificadas ou analisadas se as imagens forem depreendidas "dentro do contexto sociocultural do indivíduo e de acordo com as imagens mentais que este incorpora". Por esse motivo, elas são polissêmicas viabilizando significados e interpretações que se diversificam a partir da memória, visão, contexto, expectativas e desejos do espectador.

Ainda de acordo com esse autor, a justificativa para a criação de imagens está associada a uma causa ou finalidade específica, seja ela de caráter

[...] religioso, político, ideológico, publicitário, educacional, informacional, ilustrativo, artístico, etc., sempre com uma ligação às características sociais, culturais, religiosas, econômicas etc., de cada sociedade ou grupo [...] (RODRIGUES, 2007, p. 68).

Por esse motivo, muitas imagens não são reconhecidas, assimiladas, interpretadas por indivíduos que fazem parte de determinadas culturas pelo fato deles não possuírem conhecimentos adequados para entendê-las, uma vez que os sujeitos atribuem sentido às coisas pela maneira como as utilizam ou as integram e associam em suas práticas cotidianas.

Assim, as imagens são interpretadas e analisadas de acordo com a leitura de mundo, a memória e a cognição dos seus leitores, assim como aponta Joly (2002, p. 263): 
Memorizadas ou esquecidas, as imagens fazem, contudo, parte de nossa experiência do mundo, que nós integramos, evidentemente, cada um à sua maneira em função de nossa história e do seu condicionamento. A forma como articulamos a história pessoal e a história coletiva pertence-nos sem dúvida, mas participa também ativamente na própria vitalidade das imagens.

Para esse autor a compreensão de uma imagem está associada à memorização, uma vez que só se reconhece efetivamente aquilo que já se conhece e que não foi apagado da memória. Embora cada leitor seja único e interprete de maneira unívoca uma imagem, considerando os seus conhecimentos prévios e capacidade interpretativa, tal intepretação pode sofrer variações de acordo com as circunstâncias. Com base nas ideias de Umberto Eco, Joly (2002) ressalta que as imagens carregam consigo um conjunto de informações que podem ser identificadas, analisadas, interpretadas, (res)significadas na perspectiva de três elementos: o autor ou criador (o que ele quis dizer), a obra (o que a obra diz) e o leitor ou receptor (o que ele privilegiou na mensagem).

Nesse entendimento, a análise da informação imagética consiste em uma atividade baseada nos aspectos cognitivos, levando em consideração que contempla a dimensão expressiva da imagem (cor, forma, textura, etc.), informações denotativas (objetos, eventos, lugares, etc.) e conotativas (abstração, sentimentos, etc.).

As metodologias elaboradas e aplicadas para a realização dessa operação aliadas aos diversos tipos de associações mentais, podem viabilizar a realização da distinção dos elementos constituintes da imagem e o seu respectivo conteúdo para fins de representação e recuperação. Contudo, é possível inferir também que a análise da informação imagética depende da capacidade imaginativa, da cognição, memória, interpretação e percepção do mundo desse sujeito indexador.

Desse modo, merece ainda uma atenção especial estudar os aspectos cognitivos da análise de xilogravuras, em especial, xilogravuras de cordel, as quais são inspiradas na poesia e trazem consigo a originalidade dos xilógrafos retratando elementos reais e imaginários. Para tanto, são apresentadas a seguir questões concernentes a essa tipologia de recurso imagético.

\section{XILOGRAVURAS NA LITERATURA DE CORDEL}

Considerando que as imagens se configuram como um dos principais meios de comunicação entre os homens, as gravuras são registros do conhecimento que nascem da necessidade desses sujeitos se expressarem. Dessa forma, elas existem desde a pré-história até os dias atuais e integram-se ao processo de reprodução e representação que revela a arte popular e o domínio do homem na matéria (JORGE; GABRIEL, 1986, p. 13).

O processo de elaboração de gravuras deve ser realizado em uma dada matéria cujo recurso determina o nome da arte. "Por exemplo, se a gravura for feita de papelão, será chamada de papelogravura, se for feita na madeira, xilogravura, e assim ocorre com as demais técnicas." (CARVALHO, 2015, p. 50).

A xilogravura consiste em uma arte antiga talhada em suporte de madeira, denominado como matriz, e foi utilizada inicialmente para copiar e reproduzir outras obras de arte (desenhos, pinturas, etc.) no intuito de torná-las conhecidas (LICARIÃO, [199-?]).

De acordo com Souza (1980 apud MACHADO; ALBUQUERQUE, 2016, p. 857), para a constituição dessa arte, o xilógrafo recorta as partes da madeira até formar a estampa que 
pretende através de desenhos e/ou textos nas partes deixadas em relevo na matriz. Sendo assim, para a realização da sua impressão aplica-se a tinta no suporte em madeira utilizando a prensa para a transferência da imagem e/ou do texto para outro suporte.

A palavra "xilografia" é formada de dois vocábulos gregos (Xulon e Graphein) e significa literalmente "escrita em madeira" ou "gravação em madeira". Diante disso, Costella (1987) ressalta que a ação de gravação em uma matriz de madeira é denominada "xilografia" e a impressão obtida através desse ato é nomeada "xilogravura".

Para Carvalho (2014), xilogravura é o resultado do corte em madeira de tipos diferentes, dentre as quais: casca de cajá, mogno, pinho, pau-amarelo, imburana. A seleção do tipo de madeira depende da preferência de cada xilógrafo. Quanto aos instrumentos de incisão, a goiva, o formão, o estilete, a faquinha e o buril são os principais instrumentos de trabalho desses artistas.

Sobre as origens da Xilografia, Herskovits (1986) destaca que, apesar do fato de os chineses terem sido os primeiros povos a utilizarem a impressão tabular, no ano de 770 no Japão foi realizada a primeira impressão em massa de um milhão de exemplares de talismãs como representação da sabedoria búdica.

Assim, embora não haja consenso em relação ao período que a xilogravura foi inicialmente criada, Costella (2003) explica que o registro do livro datado mais antigo é denominado "Sutra Diamante"; ele foi impresso por Wang Chieh no ano de 868 e descoberto apenas no ano de 1900, em uma caverna próxima da cidade chinesa de Tun-huang.

Para Grangeiro (2002), as xilogravuras começaram a surgir com maior frequência na Europa após a expansão do papel na Idade Média para reproduzir imagens sacras por meio de iluminuras. Desse modo, a religião contribuiu para a propagação das xilogravuras como meio para a divulgação de sua filosofia.

Em posição complementar, Botey (1997, p. 47, tradução nossa) destaca:

[...] a gravura em madeira tem seus antecedentes nas cartas de jogo, já conhecidas pelos italianos nos últimos anos do século XIII e pelos franceses e alemães no início do XIV, as quais, sem dúvida, poderiam sugerir o procedimento xilográfico.

Assim, percebe-se que essa arte posteriormente começou a ser valorizada enquanto manifestação em diversos tipos de materiais como cartas de baralho, por exemplo. Com isso, outras mudanças ocorreram e viabilizaram a valorização e o reconhecimento da xilogravura enquanto arte popular, possibilitando que a classe burguesa tivesse outras visões de mundo, além de aspectos relativos à religiosidade (SOUZA, 2007). Assim, a xilogravura ganhou novos contextos de aplicações e representações, não se limitando apenas às imagens religiosas e cartas de baralho.

Com o avanço tecnológico foram surgindo, porém, algumas soluções alternativas ao emprego da madeira, sem que isso afetasse a expressão criadora da imagem. "As variações de material e de técnica fazem crer que a xilogravura se atualiza, sem, contudo, romper com os procedimentos mais arraigados dessa manifestação da cultura popular." (CARVALHO, 2014, p. 190).

Em linhas gerais, verifica-se a relação intrínseca das xilogravuras com a cultura de cada povo. Essas imagens antecederam as fotografias e no decorrer da história da humanidade têm se configurado fontes de informação para letrados e iletrados, expressando pontos de vistas críticos que suscitam reflexões e leituras mentalizadas em contextos e temáticas plurais. 
Franklin (2007, p. 11) destaca que no Brasil o artista usa essas imagens para retratar o seu mágico universo, "onde anjos se misturam com demônios, beatos com cangaceiros, princesas com boiadeiros, todos envolvidos nas crenças, esperanças, lutas e desenganos".

Se constitui como foco do presente estudo as xilogravuras ou gravuras em madeira cujas ilustrações expressivas são apresentadas em capas de folhetos de cordel. "Embora não possa ser considerada irmã gêmea do folheto de cordel, a xilogravura popular nordestina com ele se identifica de tal modo que passou a competir, não raro em condições vantajosas, com as formas tradicionais de ilustração de suas capas." (CARVALHO, 2014, p. 189).

De acordo com Aguiar et al. (2008, p. 2), a "literatura de cordel é uma poesia narrativa e popular escrita em versos, rimada e metrificada". Trata-se de um material informacional que reflete a cultura e o modo de pensar de um povo, ou seja, possui um caráter social. Desse modo, o cordel tem sido reconhecido como "artefato informacional e memorialístico" e como "um gênero literário de peso na memória da tradição" (ALBUQUERQUE et al., 2016, p. 14), atravessando o período da ditadura militar no Brasil e se inserindo no contexto escolar e acadêmico como instrumento de pesquisas científicas, retratando o rico imaginário popular.

Relacionados a essa técnica existem dois tipos de xilógrafos: a) o artista que apenas ilustra os folhetos escritos por outros, ou seja, são apenas gravadores; b) o artista que ilustra seus próprios folhetos, isto é, são gravadores e poetas (LIRAIÃO, [199-?]). Assim sendo, "a imaginação pessoal de cada poeta na literatura de cordel se une à tradição para a criação das narrativas que são retratadas pelas xilogravuras." (MENEZES, 2010, p. 184).

Quanto ao processo de criação de uma xilogravura para folhetos de cordel, Carvalho (2014, p. 189) explica que:

O artista se inspira ou é solicitado por alguém. Passa para o papel o desenho ou desenha diretamente na madeira e o desenho é cortado de acordo com aquelas linhas. [...] No que tange ao cordel, aquela matriz, depois de preparada, é entregue para o gráfico e o gráfico acopla à composição.

De acordo com Hata (1999) e Ribeiro (2006), os assuntos preferidos nessas xilogravuras são: Lampião e Maria Bonita, a fauna e a flora nordestinas, festejos populares, elementos míticos, cangaço e religiosidade. Adicionalmente, de acordo com Arantes e Okabayashi (2004), o xilógrafo pernambucano José Francisco Borges, mais conhecido como J. Borges e considerado um dos artistas nacionais mais reconhecidos no campo das xilogravuras, apresenta a seguinte classificação de acordo com as características e a temática abordada em suas obras:

a) Criações por encomendas para assuntos especializados: trabalhos xilográficos para capas de discos, livros, impressos em tecido, cartazes, rótulos, folhetos promocionais, etc.

b) Criações dirigidas para o mercado da arte em geral (intelectuais, artistas, colecionadores de arte, etc.), de acordo com os seguintes assuntos:

- Personagens fantásticos do imaginário regional como a mulher-cobra, os dragões e mulas sem cabeça, entre outros;

- Enredos e personagens de folhetos de cordel: pavão misterioso e a chegada da prostituta no céu, etc.;

- Personagens emblemáticos da cultura nordestina: Padre Cícero, Lampião, Maria Bonita, a seca no sertão, retirantes, corte de cana, forró, festas de São João, vaquejada, bumba-meu-boi, cavalo marinho, etc.; 
- Situações do cotidiano: bares e cabarés, brigas de galo, jogos de bicho, etc.

Além disso, os temas mais requisitados para a elaboração das xilogravuras são: o cotidiano do pobre, p cangaço, o amor, os castigos do céu, os mistérios, os milagres, os crimes e corrupção, os folguedos populares, a religiosidade, enfim todo o universo cultural do povo nordestino (MACHADO, 2003) ${ }^{6}$.

Também é possível visualizar o traço simples da arte xilográfica, o que configura como o elemento característico desse recurso informacional. Algumas xilogravuras são apresentadas em preto e branco e outras são coloridas. Entretanto, é importante ressaltar que o uso de cores ou não independe da temática a ser retratada nessa arte.

Outro aspecto importante a ser considerado nas xilogravuras é o fato de que elas expressam elementos reais e imaginários. Para Laplantine e Trindade (1997, p. 12), “o real é a interpretação que os homens atribuem à realidade. $O$ real existe a partir de ideias, dos signos e dos símbolos atribuídos à realidade percebida". Por outro lado, o imaginário "[...] utiliza o simbólico para exprimir-se e existir, e, por sua vez, pressupõe a capacidade imaginária" (LAPLANTINE; TRINDADE, 1997, p. 23).

Os elementos reais representados nas xilogravuras estão associados aos aspectos provenientes de uma determinada realidade, contexto ou acontecimento, interpretados pelos xilógrafos. Por outro lado, os elementos imaginários representados espontaneamente nessas imagens são provenientes das invenções fantasiadas na cognição desses artistas ou baseados em estórias e lendas contadas em uma determinada região. Nesse último caso, a realidade se configura como um produto do imaginário.

Portanto, a representação de uma arte em outra arte, neste caso a xilogravura na literatura de cordel, se constitui como uma maneira de analisar as relações das diferentes artes entre si e o aspecto representativo e interpretativo que elas incitam. Desse modo, se constitui como foco deste estudo a indexação de xilogravuras ou gravuras em madeira cujas ilustrações expressivas são apresentadas em capas de folhetos de cordel.

Esses recursos imagéticos possuem relação direta com a literatura de cordel, principalmente na região do nordeste do Brasil, local onde obteve e obtém maior relevância para a cultura popular. Essas imagens se fizeram presentes nas capas dos folhetos, e não muito frequente, em páginas no interior desses folhetos, no intuito de antecipar e representar o seu conteúdo.

Na publicação do Diário Oficial da União de 20 de agosto de 2018, junto à notícia de que o cordel foi registrado pelo IPHAN como patrimônio cultural do Brasil, foi apresentada também a relação das xilogravuras com esses folhetos.

As capas [dos folhetos de cordel] merecem um destaque à parte em função da imagem que ilustra o folheto. Não se trata de uma mera ilustração do texto, mas tem função mnemônica, condensando a trama da narrativa, e função metafórica, multiplicando sentidos e significados que abarcam a observação do cotidiano e da vida social. Dentre todas as técnicas imagéticas já empregadas, a arte da xilogravura acabou conferindo uma identidade visual ao folheto de cordel (BRASIL, 2018, p.12).

As pessoas que não sabiam ler os cordéis conseguiam compreender o sentido sequencial e o conteúdo apresentado nesses folhetos por meio das imagens (FEBVRE; MARTIN, 1992). Observa-se, nesse sentido, a importância das xilogravuras para a

\footnotetext{
${ }^{6}$ Informação disponível em: http://basilio.fundaj.gov.br/pesquisaescolar/index.php?option=com content\&view=article\&id=394\&ltemid=1 Acesso em: 21 jan. 2019.
} 
disseminação da cultura popular e representação da escrita por meio das imagens, como forma de facilitar a compreensão das pessoas que não sabiam ou ainda não sabem ler. Elas se tornaram acessíveis às classes populares e são imprescindíveis tanto no processo de representação da narrativa de cordel como na construção histórica da cultura popular brasileira.

Diante disso, observa-se que o pensamento criador do artista no campo da xilogravura de folhetos de cordel é inspirado na poesia. Há uma notável fidelidade ao conteúdo essencial do folheto. "Isso significa dizer que o gravador não cria, num sentido de autonomia, de independência. Sua arte se faz sentir em função da obra, do texto. Ajuda, induz à percepção do fenômeno." (CARVALHO, 2014, p. 129).

Nas xilogravuras se unem os elementos de rudeza técnica com o refinamento de uma exata adequação de meios e mensagens, no intuito de atingir níveis expressivos de descrições e de manifestações.

\section{PERCURSO METODOLÓGICO}

Os procedimentos metodológicos deste estudo foram empreendidos a partir da pesquisa bibliográfica para a fundamentação teórica do assunto estudado, seguido de um delineamento de caráter exploratório e descritivo contemplando um grupo experimental de sujeitos indexadores que trabalham em unidades de informação que possuem acervos de cordel para a aplicação da técnica de protocolo verbal individual, cuja análise dos dados obtidos foi efetuada por meio da técnica de análise de conteúdo de Bardin (2011). Sob esse viés, esta pesquisa também é caracterizada como um estudo de caso, uma vez que foram realizadas investigações com indexadores que trabalham em instituições que possuem acervos com folhetos de cordel.

Dessa forma, incialmente foi realizado um levantamento de produções científicas em fontes de informação como bases de dados e repositórios digitais no intuito de recuperar e analisar as produções científicas que envolvam questões relativas à representação temática da informação, aos aspectos cognitivos da análise da informação imagética e à xilogravuras na literatura popular de cordel.

Sendo assim, com base no escopo da pesquisa, este estudo é de cunho exploratório e descritivo. Através da pesquisa exploratória foram apresentadas questões concernentes à representação temática da informação imagética e aos aspectos cognitivos inerentes à atividade de indexação de xilogravuras de capas de folhetos de cordel realizada por profissionais da informação. De outro modo disposto, a pesquisa descritiva foi aplicada neste trabalho no intuito servir como base para as pesquisadoras realizarem a descrição e o cotejamento das formas como os sujeitos da pesquisa, indexadores, analisam as xilogravuras em capas de folhetos de cordel.

Para a realização da coleta dos dados junto a esses informantes foi aplicado um questionário com perguntas relacionadas ao perfil do colaborador da pesquisa (gênero, formação, tempo de trabalho como indexador na instituição) e a técnica Protocolo Verbal ou "Pensar alto" com vistas a "observar os conhecimentos declarativo, procedimental e metacognitivo sobre a atividade de indexação realizada pelos mesmos" (FUJITA; RUBI, 2007, p.143). Para Rubi (2009, p. 82), “[...] Protocolo Verbal consiste na gravação da exteriorização verbal do pensamento de um ou mais indivíduos durante a realização de uma tarefa". Segundo Fujita (2003, p. 51), "essa exteriorização é gravada e transcrita literalmente, produzindo protocolos verbais. Protocolos são, geralmente, definidos como relatos verbais dos 
processos mentais conscientes dos informantes". Essa etapa foi efetuada no presente estudo para que fossem descritas e cotejadas as formas como os sujeitos da pesquisa analisam as xilogravuras em capas de folhetos de cordel.

As principais contribuições referentes à técnica de Protocolo Verbal para esta pesquisa, bem como para os demais estudos ancorados no contexto da organização e representação do conhecimento são apresentadas no Quadro 1.

Quadro 1 - Principais contribuições da Técnica de Protocolo Verbal

\section{PRINCIPAIS CONTRIBUIÇÕES DA TÉCNICA DE PROTOCOLO VERBAL}

Fornece informações sobre os processos mentais utilizados pelos(as) indivíduos(as) na
realização da tarefa de análise e síntese de conteúdo, a partir das verbalizações.
Possibilita a investigação de estratégias de identificação e seleção de conceitos.
Oportuniza observar as percepções dos(as) sujeito(as) em relação às características do
item informacional analisado.
Possibilita identificar aspectos metacognitivos e sociocognitivos da leitura e indexação
realizada pelo(as) sujeitos(as).
Viabiliza a identificação, categorização e comparação de estratégias metacognitivas
dos(as) participantes.
Revela eventos cognitivos para fins de construção de métodos e técnicas de indexação
de textos não verbais (podendo também corroborar para textos verbais).
Fonte: Elaborado pelas autoras (2018).

Fonte: Elaborado pelas autoras (2018).

Nesta pesquisa foi aplicado o Protocolo Verbal Individual, uma vez que a coleta dos dados foi feita de forma individual com os participantes. A descrição e síntese dos procedimentos de coletas de dados através dessa técnica é apresentada na subseção 5.5.

Além disso, para a análise dos dados coletados, foi utilizada a técnica de análise de conteúdo de Bardin (2011) cujo procedimento adotado foi por "milha", em que foram identificadas as categorias durante a trajetória da análise e sua nomeação foi criada posteriormente - conforme pode ser visualizado na análise e discussão dos resultados.

Quanto à abordagem, a pesquisa é caracterizada como qualitativa, uma vez que neste estudo são compreendidos aspectos relativos à cognição e análise da informação imagética, bem como são avaliadas qualitativamente as formas como os sujeitos da pesquisa analisam as xilogravuras em capas de folhetos de cordel.

\subsection{Sujeitos da pesquisa}

Participaram do presente estudo sujeitos que atuam em duas instituições, são elas: Fundação Casa de José Américo (FCJA), em João Pessoa/Paraíba, e Biblioteca Central Zila Mamede da Universidade Federal do Rio Grande do Norte (BCZM/UFRN), localizada em Natal/Rio Grande do Norte. Ambas as instituições foram selecionadas, tendo em vista que possuem projetos com acervos de Literatura de Cordel. Além disso, essa seleção se deu pelo fato de que na organização do acervo são realizados processos técnicos por profissionais da informação e que está sendo levada em conta a classificação idealizada por Albuquerque $(2011)^{7}$ no processo de classificação e organização dessa espécie documental. Ademais, a

\footnotetext{
7 Albuquerque (2011) propôs, em sua Tese de Doutorado, classes temáticas consideradas apropriadas à classificação da literatura de cordel e que podem ser utilizadas em acervos que compõem essa espécie documental.
} 
seleção dessas unidades de informação se deu pela viabilidade para a coleta dos dados e pela disponibilidade das participantes da pesquisa.

Nesse sentido, participaram desta pesquisa duas bibliotecárias, uma vez que o estudo tem como objetivo trabalhar com indexadores que atuam diretamente com os acervos de Literatura de Cordel. No grupo de indexadores, através da aplicação do questionário sobre os dados do perfil dos colaboradores, observou-se que são bibliotecárias com tempo de profissão médio de 9 anos nas instituições e ambas possuem especialização. Observou-se ainda que as profissionais, embora trabalhem diretamente com acervos de Literatura de Cordel, ressaltaram que nunca realizaram indexação de xilogravuras. Portanto, a pesquisa objetivou identificar os aspectos cognitivos inerentes à atividade de indexação de xilogravuras de capas de folhetos de cordel efetuada por profissionais da informação. No intuito de manter a integridade e a ética na pesquisa, os nomes das participantes foram mantidos em sigilo. Dessa forma, tais profissionais são denominadas no presente estudo como Indexadora A e Indexadora B.

\subsection{Material selecionado}

Considerando que o pensamento criador do artista no campo da xilogravura de folhetos de cordel é inspirado na poesia, foram selecionados os folhetos de cordel cujas xilogravuras e poesias foram produzidas pelo poeta e xilógrafo Marcelo Soares. A escolha desse poeta e xilógrafo está atrelada ao fato de que o mesmo é considerado um dos mais significativos poetas cordelistas da atualidade, assumindo a presidência de honra da Academia de Cordel do Vale do Paraíba. Sendo assim, foi realizada uma busca da produção literária desse poeta e artista no site "Memórias da Poesia Popular: informação sobre a vida e obra de poetas populares brasileiros". Em seguida, as pesquisadoras realizaram uma seleção aleatória dos títulos dos folhetos de cordéis cadastrados no site, produzidos e publicados pelo xilógrafo Marcelo Soares, com amostra equivalente a 10,80\% da produção literária desse artista, totalizando oito cordéis selecionados de um total de 108 (cento e oito) folhetos.

Essa atividade de seleção do material foi efetuada para a posterior aplicação da técnica de protocolo verbal individual junto aos sujeitos da pesquisa, com vistas a analisar os aspectos cognitivos da indexação das xilogravuras contidas nas capas desses folhetos. Desse modo, cada participante da pesquisa indexou seis xilogravuras, as quais estão apresentadas no Quadro 2 a seguir, levando em consideração que duas xilogravuras selecionadas foram utilizadas no intuito de servir como base para exemplificar essa técnica.

Quadro 2 - Xilogravuras de capas de folhetos de cordel selecionadas para a análise dos dados (continua)

\begin{tabular}{|c|c|c|}
\hline Capa 1 - Título: O cego namorador & $\begin{array}{c}\text { Capa 2 - Título: A crise do mensalão e } \\
\text { o caso da cueca }\end{array}$ & $\begin{array}{c}\text { Capa 3 - Título: } \\
\text { Direitos Humanos - todos são iguais } \\
\text { perante a lei }\end{array}$ \\
MARCELO SOARES \\
MARCELO SOARES
\end{tabular}

Fonte: Acervos de cordel das instituições da pesquisa (2018). 
Quadro 2 - Xilogravuras de capas de folhetos de cordel selecionadas para a análise dos dados (continuação)

\begin{tabular}{|c|c|c|}
\hline $\begin{array}{c}\text { Capa } 4 \text { - Título: Confissões } \\
\text { de um corno convencido }\end{array}$ & $\begin{array}{c}\text { Capa 5 - Título: Os gravíssimos pro- } \\
\text { blemas da Educação no Brasil } \\
\text { MARCELO OLECRAM }\end{array}$ & $\begin{array}{c}\text { Capa 6 - Título: O nosso Brasil precisa } \\
\text { fazer a Reforma Agrária } \\
\text { MARCBLo soAREs }\end{array}$ \\
$\begin{array}{c}\text { Onosso Brasil precisa } \\
\text { fazer a Reforma Agrária }\end{array}$ \\
\hline
\end{tabular}

Fonte: Acervos de cordel das instituições da pesquisa (2018).

Portanto, o universo da pesquisa foi constituído por oito folhetos de cordel e a amostra do estudo foi composta por seis deles. Os folhetos selecionados estão disponíveis nos acervos das instituições que fizeram parte desta pesquisa e as suas respectivas capas são apresentadas no Quadro 2.

\subsection{Procedimentos de coleta, transcrição e análise dos dados}

A coleta de dados através da técnica protocolo verbal foi realizada por intermédio da gravação da leitura das informantes da pesquisa em voz alta. Com isso, efetuou-se a transcrição das verbalizações efetuadas no decorrer da análise e indexação de cada xilogravura e, em seguida, as mesmas foram classificadas em categorias com base na técnica de análise de conteúdo de Bardin (2011). Nesse entendimento, considerando a especificidade da presente pesquisa que envolve indexação de xilogravuras, é importante ressaltar que esses procedimentos foram sistematizados de acordo com o perfil da pesquisa.

As participantes da pesquisa foram instruídas individualmente acerca da técnica do protocolo verbal. Para tanto, foram utilizadas duas das xilogravuras selecionadas no intuito de servir como base para exemplificar essa técnica. Desse modo, foi elaborada a seguinte sequência de instruções: a) reproduza o processo da análise de cada xilogravura, sem se preocupar com a presença das pesquisadoras; b) para indexar as xilogravuras de folhetos de cordel, fica a critério da participante da pesquisa a metodologia para a realização da sua análise; c) expresse verbalmente, de modo mais claro possível, as tarefas realizadas e o que se passa em sua mente no momento da análise de cada xilogravura; d) apresente as eventuais dúvidas e, sobretudo, a busca por uma solução.

Dadas essas instruções individualmente, cada participante da pesquisa iniciou a análise para fins de gravação e registro dos seus comentários. Nesse momento, as pesquisadoras tentaram manter-se fora do campo visual dos sujeitos da pesquisa, no intuito de causar o mínimo de interferência no processo de análise das xilogravuras nos folhetos de cordel.

A síntese dos procedimentos que contribuíram para a coleta e a análise dos dados é apresentada na Figura 1 a seguir.

No processo de análise e indexação das xilogravuras, as indexadoras não fizeram uso de instrumentos de controle terminológico (como Tesauros, Ontologias e Taxonomias) e não utilizaram métodos específicos voltados para a indexação de recursos imagéticos, como aqueles disponíveis para a indexação de fotografias. 
Figura 1- Síntese dos procedimentos para a aplicação da Técnica de Protocolo Verbal

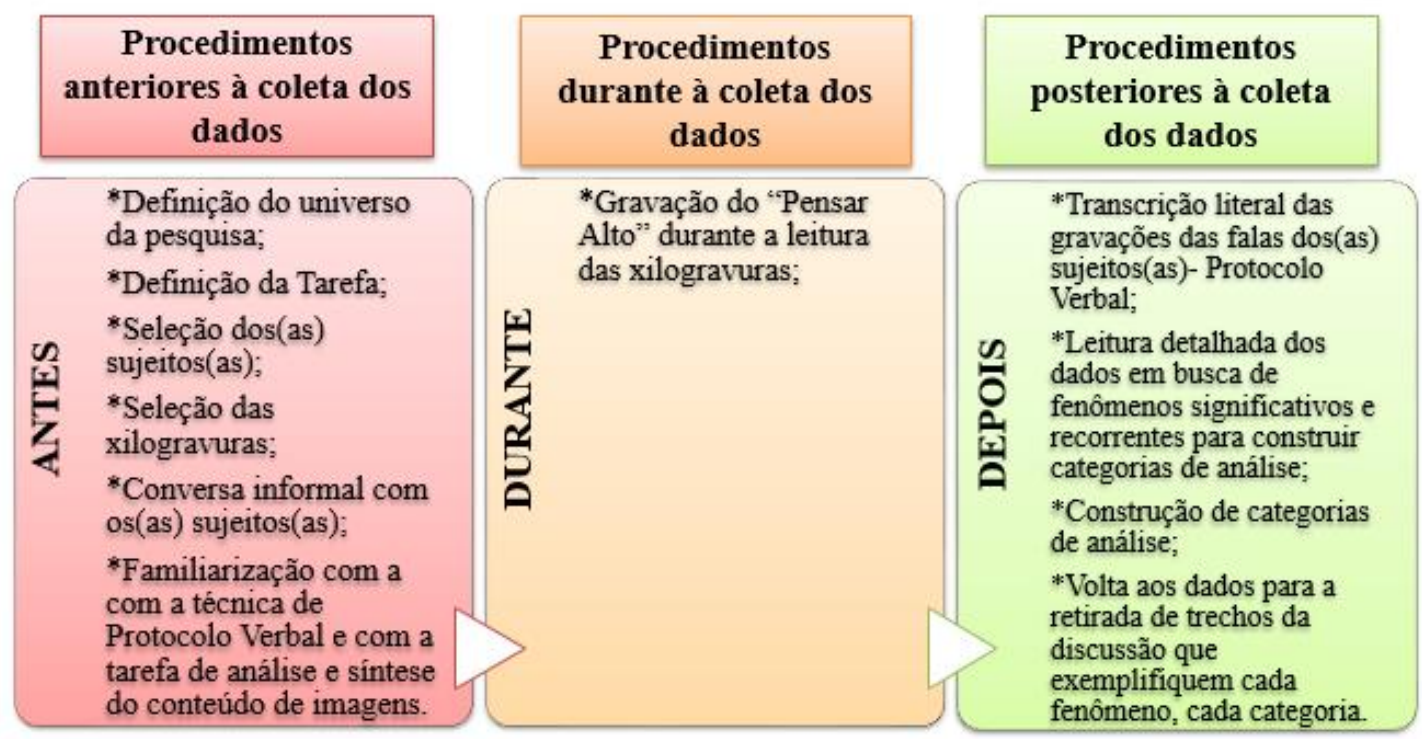

Fonte: Elaborado pelas autoras (2018).

\section{ANÁLISE E DISCUSSÃO DOS RESULTADOS}

Mediante a coleta e análises dos dados, foi possível investigar e identificar os procedimentos efetuados pelas indexadoras no momento da indexação das xilogravuras de capas de folhetos de cordel. As verbalizações e os comentários acerca de cada xilogravura analisada pela indexadora A e pela indexadora B encontram-se apresentados nos Quadros 3 e 4.

Quadro 3- Comentários e verbalizações da indexadora A (continua)

\begin{tabular}{|c|l|}
\hline $\begin{array}{c}\text { Título do folheto cuja } \\
\text { xilogravura foi analisada }\end{array}$ & \multicolumn{1}{c|}{ Transcrições dos relatos verbais } \\
\hline & $\begin{array}{l}\text { Bom, vou analisar esse cordel intitulado "O cego namorador". Geralmente eu } \\
\text { analiso primeiro o título e verifico se a xilogravura tem a ver com o título. } \\
\text { Procuro reconhecer o autor da xilogravura. Que geralmente tem xilógrafos } \\
\text { que apresentam as mesmas características no desenho. Então eu já verifico } \\
\text { se...se, já é um conhecido, é.. se tem alguma informação do xilógrafo, porque } \\
\text { as vezes vem o nome dele e as vezes não vem e vou para a folha de rosto do } \\
\text { folheto para identificar o que tem em relação à autoria, se o texto corres- } \\
\text { ponde ao que tá presente na xilogravura e também se tem informações no } \\
\text { verso. Então percebo que nesse folheto Marcelo Soares é o autor e xilógrafo } \\
\text { da capa. Nessa xilogravura da capa observo que a xilogravura do folheto } \\
\text { intitulado "o cego namorador" contém um casal. Eles se encontram de ócu- } \\
\text { los escuro, representando que são cegos né? O homem se encontra numa } \\
\text { posição que ele está apalpando as nádegas da moça ou ele está, como é que } \\
\text { se diz... se guiando por ela. Mas como o título é o cego namorador... a ques- } \\
\text { tão aqui deve ser..."sentido pelo tato". Embora eu creio que temos que ler o } \\
\text { conteúdo do folheto para entender melhor e para poder indexar. Portanto, } \\
\text { olhando aqui o texto do folheto, percebo que essa xilogravura aqui represen- } \\
\text { ta o cego usando os seus sentidos. Para indexar essa xilogravura seria com o } \\
\text { termo: "Cego namorando". }\end{array}$ \\
\hline
\end{tabular}

Fonte: Dados da pesquisa (2018). 
Quadro 3- Comentários e verbalizações da indexadora A (continuação/continua)

\begin{tabular}{|c|c|}
\hline $\begin{array}{l}\text { Título do folheto cuja } \\
\text { xilogravura foi analisada }\end{array}$ & Transcrições dos relatos verbais \\
\hline 2 - A crise do Mensalão & $\begin{array}{l}\text { Esse aqui também é de Marcelo Soares e é intitulado "A crise do Mensalão e } \\
\text { o caso da cueca". Na capa tem a xilogravura que representa um homem de } \\
\text { barba, é... uniformizado e tem um.. como se chama...um balãozinho, em que } \\
\text { ele fala: "O Brasil é um país literalmente engraçado. Entulhado de problemas } \\
\text { e crises por todo lado. Por causa do Mensalão e o dólar no cuecão tô ficando } \\
\text { abestalhado. É.. essa imagem, a xilogravura do homem, parece uma caricatu- } \\
\text { ra de Lula. É porque o homem está de barba, bigode, palitó, embora eviden- } \\
\text { cia a questão do mensalão, um problema de crise no Brasil que a gente sabe } \\
\text { que está relacionada a isso. Lendo brevemente também o texto do folheto, } \\
\text { eu indexaria essa xilogravura com os termos: política- Brasil - Crise ou } \\
\text { Política-Brasil. Ou poderia inverter também: Política-Crise-Brasil. }\end{array}$ \\
\hline 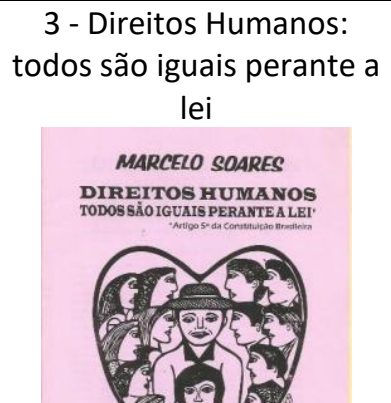 & $\begin{array}{l}\text { Estou lendo o título e o texto do folheto. Trata-se do artigo 5o da constituição } \\
\text { brasileira, é... com um homem de chapéu e várias pessoas ao redor...Essa } \\
\text { xilogravura aqui a princípio se refere à constituição. Analisando o conteúdo } \\
\text { do folheto realmente ela pode ser indexada como: Direitos Humanos - Brasil } \\
\text { - História. }\end{array}$ \\
\hline $\begin{array}{l}4 \text { - Confissões de um cor- } \\
\text { no convencido } \\
\text { MARCELO OLECRAM }\end{array}$ & $\begin{array}{l}\text { Esse aqui é novamente de Marcelo Soares e é colocado o Pseudônimo dele } \\
\text { "Olecram". Cordel intitulado "Confissões de um corno convencido. Estou } \\
\text { vendo o conteúdo que menciona as estranhas confissões de um corno con- } \\
\text { vencido. Eu não tinha observado a xilogravura...mas agora vejo que tem um } \\
\text { casal e o rapaz possui dois chifres e a moça está como se estivesse puxando } \\
\text { ele pela camisa. Eles estão caminhando. No caso aqui eu acho que indexaria } \\
\text { como...uma história de fixão?!....conto?!....Eu aqui eu indexaria como: corno - } \\
\text { confissões. }\end{array}$ \\
\hline $\begin{array}{c}5 \text { - Os gravíssimos pro- } \\
\text { blemas da Educação no } \\
\text { Brasil }\end{array}$ & $\begin{array}{l}\text { Esse cordel aqui intitulado "Os gravíssimos problemas na educação do Brasil" } \\
\text { também de autoria de Marcelo Soares e Xilogravura de Marcelo Soares é de } \\
\text { 2000. Tem uma xilogravura como se fosse com o desenho de uma sala de } \\
\text { aula, tem um quadro, um professor ensinando e tem vários alunos é... obser- } \\
\text { vando a explicação do professor e no quadro está escrito "desvio de verbas } \\
\text { do FUNDEF, professores mal remunerados, falta de reciclagem profissional. É } \\
\text { de Timbaúba, Pernambuco. Vou ver aqui o que é que tem no conteúdo da } \\
\text { poesia... quer dizer que esse aqui é relacionado aos problemas da educação } \\
\text { no Brasil, é a realidade da Educação do Brasil. Eu indexaria dessa forma: Edu- } \\
\text { cação- problemas; Educação - Brasil. Ou poderia usar três termos juntos: } \\
\text { Educação- Brasil-Problemas. }\end{array}$ \\
\hline
\end{tabular}

Fonte: Dados da pesquisa (2018). 
Quadro 3- Comentários e verbalizações da indexadora A

(continuação)

\begin{tabular}{|c|c|}
\hline $\begin{array}{l}\text { Título do folheto cuja } \\
\text { xilogravura foi analisada }\end{array}$ & Transcrições dos relatos verbais \\
\hline $\begin{array}{l}6 \text { - O nosso Brasil precisa } \\
\text { de fazer a reforma agrária } \\
\text { MARcBLo soAres } \\
\text { 0 nosso Brasil precisa } \\
\text { fazer a Reforma Agrária }\end{array}$ & $\begin{array}{l}\text { Esse aqui é de Marcelo Soares também e a xilogravura é do mesmo autor. Na } \\
\text { xilogravura tem várias casinhas, uma igrejinha, aqui deve ser umaplantação.. } \\
\text { como se fosse plantação de cana, tem umas pessoas assim...como se fosse de } \\
\text { chapéu com arma e tem outras pessoas só observando. Deixa eu ver aqui os } \\
\text { versos... pela xilogravura... Essa aqui eu indexaria como: Reforma Agrária - } \\
\text { Brasil. }\end{array}$ \\
\hline
\end{tabular}

Fonte: Dados da pesquisa (2018).

Quadro 4- Comentários e verbalizações da indexadora B

(continua)

\begin{tabular}{|c|c|}
\hline $\begin{array}{l}\text { Título do folheto cuja } \\
\text { xilogravura foi analisada }\end{array}$ & Transcrições dos relatos verbais \\
\hline 1 - O cego namorador & $\begin{array}{l}\text { Bom, vejo que esse folheto é de autoria de Marcelo Soares, é intitulado "O } \\
\text { cego namorador" e a xilogravura também é do autor Marcelo Soares. Estou } \\
\text { observando aqui a biografia dele no verso do folheto. Interessante, Marcelo } \\
\text { é de Olinda, Pernambuco, é artista gráfico, poeta, pintor e gravador. Acho } \\
\text { muito interessante esses cordelistas. Eles, em versos, contam toda a história } \\
\text { real ou imaginária. Vejo aqui dentro o conteúdo do cordel e estou perceben- } \\
\text { do aqui rapidamente que ele diz que o poema se trata de um cego namora- } \\
\text { dor, ele ficava na praia e gostava muito de apalpar, de pegar. Se eu não me } \\
\text { engano tem uma namorada, mas não dispensa nenhuma mulher, o que pas- } \\
\text { sar...ele não dispensa. Realmente eu não estou lendo o conteúdo integral do } \\
\text { folheto. O que estou vendo que está sendo representado na xilogravura é um } \\
\text { cego apalpando o glúteo de uma moça. } \\
\text { A gravura também poderia dizer que seria: sexo e deficiência visual. Não que } \\
\text { ela apresente exatamente o sexo. Mas tem um apelo sexual, pela maneira } \\
\text { que ele está tocando ela. Como termos para indexar a xilogravura eu coloca- } \\
\text { ria: deficiência visual-namoro. }\end{array}$ \\
\hline (3) & $\begin{array}{l}\text { Esse cordel também de autoria de Marcelo Soares e xilogravura de Marcelo } \\
\text { Soares trata do Mensalão. Termo que não é desconhecido para ninguém. } \\
\text { Vejo que a figura dá a entender que seja o presidente Lula com um discurso } \\
\text { irônico.. né? porque ele fala assim: "O Brasil é um país literalmente engraça- } \\
\text { do. Entulhado de problemas e crises por todo lado. Por causa do Mensalão e } \\
\text { o dólar no cuecão tô ficando abestalhado". Então, conteúdo do cordel e essa } \\
\text { fala também retrata acerca dos dólares na cueca né?, política!. Vejo na gra- } \\
\text { vura o ex presidente Lula, mas no caso aqui da época em que o cordel foi } \\
\text { criado observo que foi de } 2005 \text {. Deixa eu folhear e ler o cordel. Lula ainda era } \\
\text { presidente na época. Compreendo que o termo a ser indexado pelo nome } \\
\text { dele não seria esse porque usamos outro termo nas indexações relativas ao } \\
\text { Presidente Lula. É o nome dele por extenso: Luís Inácio Lula da Silva. Então os } \\
\text { termos poderia ser: Presidente Luís Inácio Lula da Silva - crise do mensalão; } \\
\text { Brasil - aspectos políticos. Porque são todos esses aspectos políticos mesmo } \\
\text { que são vistos de maneira simbólica na gravura. }\end{array}$ \\
\hline
\end{tabular}

Fonte: Dados da pesquisa (2018). 
Quadro 4- Comentários e verbalizações da indexadora B

(continuação)

\begin{tabular}{|c|c|}
\hline $\begin{array}{l}\text { Título do folheto cuja } \\
\text { xilogravura foi analisada }\end{array}$ & Transcrições dos relatos verbais \\
\hline 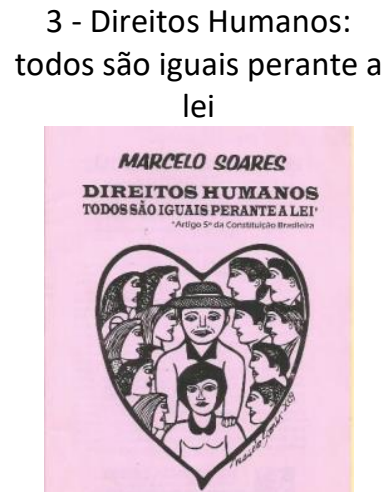 & $\begin{array}{l}\text { Aqui também é outro cordel de autoria de Marcelo Soares e a xilogravura é } \\
\text { do mesmo autor. Na xilogravura tem várias pessoas com diversas caracterís- } \\
\text { ticas e perfis dentro de um coração. Estou folheando para ver brevemente o } \\
\text { conteúdo do folheto de cordel. Mas a xilogravura dá a entender que são } \\
\text { cidadãos brasileiros, todos estão reunidos dentro de um coração. Essa xilo- } \\
\text { gravura poderia ser indexada pelo termo: Direitos Humanos; Brasil - condi- } \\
\text { ções sociais; Brasil- igualdade social. Se bem que aqui não tem exatamente } \\
\text { isso na figura. Mas o conteúdo em si mostra uma sociedade. Apresenta cida- } \\
\text { dãos, dentro de um coração, de um mesmo espaço. }\end{array}$ \\
\hline 4-Confi & $\begin{array}{l}\text { Então, vejo que a xilogravura do folheto intitulado "Confissões de um corno } \\
\text { convencido" também é de autoria de Marcelo Soares e é de } 2006 \text { e represen- } \\
\text { ta um homem que aparentemente foi traído. Vejo ele abordando uma mu- } \\
\text { lher e ela está empurrando ele com a mão. Aparentemente sendo rejeitado } \\
\text { pela mulher que está de cabeça levantada, aparentemente orgulhosa. Ele } \\
\text { apresenta-se com dois chifres que socialmente simboliza o homem corno.... } \\
\text { engraçado isso. Estou olhando de maneira breve o texto. Para indexar essa } \\
\text { imagem seria utilizado o termo "traição" como um termo principal e único. } \\
\text { Não encontro outra coisa não. }\end{array}$ \\
\hline 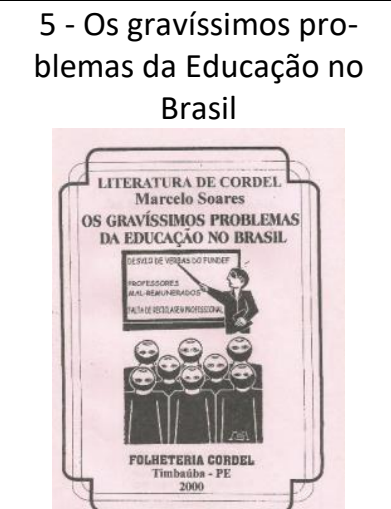 & $\begin{array}{l}\text { Esse outro cordel aqui é intitulado "Os gravíssimos problemas da Educação } \\
\text { no Brasil", é de autoria de Marcelo Soares e a xilogravura também é de auto- } \\
\text { ria dele. Estou folheando o cordel para ver brevemente o seu conteúdo e } \\
\text { tentar correlaciona-lo com a imagem. A imagem da xilogravura mostra um } \\
\text { professor em sala de aula e os alunos assistindo. Não que aqui na gravura } \\
\text { tenha isso, mas a figura, o texto presente na xilogravura evidencia a corrup- } \\
\text { ção, o desvio do dinheiro público. Então os termos para representar a xilo- } \\
\text { gravura seria: Educação - Brasil. Desvio de verba pública. Professores. }\end{array}$ \\
\hline $\begin{array}{l}\text { - O nosso Brasil precisa } \\
\text { de fazer a reforma agrária } \\
\text { MARcelo soares } \\
\text { 0 nosso Brasil precisa } \\
\text { fazer a Reforma Agrária }\end{array}$ & $\begin{array}{l}\text { Esse cordel aqui é intitulado "O nosso Brasil precisa fazer a reforma agrária" } \\
\text { é de autoria de Marcelo Soares e a xilogravura também é do mesmo autor. } \\
\text { Estou folheando e lendo o conteúdo do material. Bom, pelo próprio título o } \\
\text { primeiro descritor seria "reforma agrária". Aqui eu vejo a reforma agrária } \\
\text { que é necessária as vezes usar forças armadas, porque é assim que eles se } \\
\text { impõem. Não vejo a polícia nessa gravura, aqui a gente sabe que a represen- } \\
\text { tação da reforma agrária não está na gravura, mas sabemos que a reforma } \\
\text { agrária é uma questão política, é uma questão econômica e social. Estou } \\
\text { vendo que eles usam a terra para se sustentar. Na figura tem a representa- } \\
\text { ção da agricultura, moradia, eu acredito que aqui deve ser uma igreja, talvez } \\
\text { isso aqui seja uma escola e o armamento. Mas a xilogravura poderia ser in- } \\
\text { dexada pelos termos: Brasil - condições sociais. Brasil-aspectos políticos. }\end{array}$ \\
\hline
\end{tabular}

Fonte: Dados da pesquisa (2018). 
Após as investigações realizadas nos protocolos verbais, através da análise de conteúdo de Bardin (2011), foram identificados os seguintes elementos associados às estratégias metacognitivas das indexadoras na análise das xilogravuras:

\section{a) Metodologias empregadas para a indexação das xilogravuras}

Durante a aplicação da técnica protocolo verbal, constatou-se que, através dos processos cognitivos, os indexadores realizaram estratégias que viabilizaram a atividade de indexação das xilogravuras, tanto no momento da análise dessas imagens, como na etapa de apresentação dos termos representativos do seu conteúdo.

Dessa forma, como estratégia metacognitiva para a análise e indexação das xilogravuras das capas dos folhetos de cordel, as indexadoras tentaram analisar e identificar os elementos presentes nas próprias gravuras e os seus respectivos referentes. Contudo, como subsídio informacional e fonte adicional para o entendimento do conteúdo dessas imagens, verificou-se que, em todas as análises efetuadas, as participantes consultaram os títulos e os versos dos próprios folhetos cujas xilogravuras estavam sendo representadas. Além disso, no momento das análises, ambas as informantes desta pesquisa identificaram que as poesias e as xilogravuras foram construídas pelo mesmo poeta e xilógrafo Marcelo Soares - o que possivelmente fez com que as mesmas assegurassem que essa arte foi efetivamente construída em função da obra, do texto.

Durante a análise das xilogravuras, as profissionais executaram diversas tarefas: identificaram informações relevantes no texto presente no folheto, leram em voz alta as partes aparentemente mais relevantes, fizeram inferências, repetiram e reformularam as suas ideias e apresentaram questionamentos.

Desse modo, levando em conta que a indexação consiste em uma atividade que possui o caráter subjetivo, sobretudo, no que diz respeito à análise de imagens, o indexador necessita de informações adicionais acerca da xilogravura para averiguar o que ela retrata.

\section{b) Mecanismo de tradução dos termos}

Conforme visto, a indexação consiste em uma atividade que está metodologicamente associada a duas etapas intelectualmente distintas: a análise de assunto e a tradução. Nas estratégias realizadas pelas indexadoras desta pesquisa, foi perceptível que ambas as participantes identificaram e apresentaram termos que foram julgados como pertinentes para representar o conteúdo de cada xilogravura analisada. Entretanto, as mesmas não utilizaram como auxílio nenhum instrumento de controle terminológico para a tradução desses termos.

Acredita-se que o desafio da prática de indexar xilogravuras de capas de folhetos também está ligado à descrição dos elementos reais e imaginários retratados nesses recursos (transposição da mensagem visual para o código textual) e à questão terminológica, sobretudo, no controle dos homônimos, sinonímias e termos generalistas, caso o indexador utilize como base os termos provenientes dos títulos e dos textos dos folhetos. A guisa de exemplo, destacam-se os termos "cego" e "corno", os quais foram selecionados como descritores pelos indexadores e estão presentes no Quadro 5 a seguir.

Através da descrição e do cotejamento dos termos extraídos dos protocolos verbais, verificou-se que ambas as participantes identificaram e apresentaram termos iguais ou equivalentes semanticamente nas atividades de indexação, os quais foram julgados pelas mesmas como pertinentes para representar o conteúdo de cada xilogravura analisada. 
Quadro 5- Xilogravuras e descritores apresentados pelas indexadoras

\begin{tabular}{|c|c|}
\hline Xilogravuras & $\begin{array}{c}\text { Descritores apresentados pelas indexadoras para fins de representação } \\
\text { do conteúdo da xilogravura }\end{array}$ \\
\hline $\mathbf{1}$ & $\begin{array}{c}\text { Cego namorando } \\
\text { Deficiência visual - namoro }\end{array}$ \\
\hline $\mathbf{2}$ & Política - Brasil - crise \\
& Presidente Luís Inácio Lula da Silva - crise do mensalão \\
& Brasil - aspectos políticos \\
\hline $\mathbf{3}$ & Direitos Humanos - Brasil - História \\
& Direitos Humanos \\
& Brasil - condições sociais \\
Brasil - igualdade social
\end{tabular}

Fonte: Dados da pesquisa (2018).

Por exemplo, na Literatura de Cordel, o vocábulo "corno" designa a pessoa que sofreu traição amorosa pelo seu parceiro ou parceira. Tal significado também está associado aos vocábulos "chifrudo", "cornudo", "galhudo", os quais se configuram como sinonímias. Já no âmbito das xilogravuras, esses vocábulos estão relacionados à ilustração de uma pessoa com chifres de boi em sua cabeça. Entendendo isso, nota-se que as práticas de indexação e classificação devem considerar os aspectos éticos e culturais, sobretudo, pelo discurso em que uma comunidade ou grupo objetiva solidificar a sua identidade.

\section{c) Representação simbólica das imagens}

Os aspectos associados à mente humana são complexos e interferem no modo em que o indexador realiza a análise de uma xilogravura, haja vista que cada indivíduo constrói a sua unidade de sentido, que está ligada à sua capacidade de percepção, memória, inferência e dedução. Esse fato foi observado nos termos apresentados pelas indexadoras e nas seguintes verbalizações:

"Porque são todos esses aspectos políticos mesmo que são vistos de maneira simbólica na gravura [...]" (INDEXADORA A, 2018, informação verbal).

"Não que aqui na gravura tenha isso, mas a figura, o texto presente na xilogravura, evidencia a corrupção, o desvio do dinheiro público [...]" (INDEXADORA B, 2018, informação verbal).

Dessa maneira, a representação simbólica relacionada às xilogravuras e que não se encontra visível, de maneira objetiva, também suscitam diversas interpretações inerentes à capacidade imaginativa do indexador. Essa interpretação simbólica pode conduzir o indexador à identificação do(s) tema(s) retratado(s) na imagem. 


\section{d) Verbalizações de incompreensão/dúvidas acerca do conteúdo imagético}

Em alguns momentos, as indexadoras não depreenderam os elementos presentes nas xilogravuras. Tal fato é identificado pelas seguintes frases que evidenciam confusão e dúvidas, sem que sejam apresentadas estratégias para a resolução do impasse no momento da indexação, por exemplo:

"Na xilogravura tem várias casinhas, uma igrejinha, aqui deve ser uma plantação [...]" (INDEXADORA A, 2018, informação verbal, grifo nosso).

"Na figura tem a representação da agricultura, moradia, eu acho que é ali deve ser uma igreja, talvez isso aqui seja uma escola e o armamento [...]" (INDEXADORA B, 2018, informação verbal, grifo nosso).

Para a realização da indexação, é importante que o sujeito tenha conhecimento prévio acerca do conteúdo presente no recurso imagético. Todavia, isso não deve ser fator condicionante para a execução dessa operação, uma vez que, para auxiliar na compreensão da imagem analisada, podem ser extraídas informações extrínsecas em outras fontes de informação.

Como subsídio informacional e fonte adicional para a compreensão dos conteúdos e elementos retratados nas xilogravuras, verificou-se que, para sanar as dúvidas apresentadas anteriormente, as indexadoras realizaram a leitura integral nos títulos e nos versos dos foIhetos, considerando o fato de que, em linhas gerais, as xilogravuras em cordéis objetivam, ou se propõem, a representar o conteúdo dos cordéis.

\section{e) Construção de hipóteses, dúvidas e inferências no ato da indexação}

Observou-se nos relatos verbais algumas ocorrências que coadunam com as características de construção de hipóteses, dúvidas e inferências no ato da indexação realizada pelas participantes. Durante a análise das xilogravuras, as participantes fizeram suposições acerca do assunto tratado nas imagens e essas suposições foram identificadas através das seguintes expressões: "Acho que..."; "acredito que..."; "talvez....".

"No caso aqui eu acho que indexaria como...uma história de fiç̧ão?!...conto?![...]" (INDEXADORA A, 2018, informação verbal, grifo nosso).

"Na figura tem a representação da agricultura, moradia, eu acredito que aqui deve ser uma igreja, talvez isso aqui seja uma escola [...]" (INDEXADORA B, 2018, informação verbal, grifo nosso).

As hipóteses apresentadas pelas indexadoras no momento da indexação estão relacionadas ao fato de que os elementos retratados e as suas respectivas características nem sempre são identificados, em primeiro momento, na análise de imagens como as xilogravuras. Por isso a importância da aquisição de informações extrínsecas que apresentem mais referências para o reconhecimento dos conteúdos desses recursos.

\section{CONSIDERAÇÕES FINAIS}

Diante do exposto, verifica-se que os aspectos associados à mente humana são complexos e a atividade de análise de imagens requer procedimentos específicos. Isso se deve ao fato de que o indexador pode através dos termos, destacar os significados da imagem que mais lhe interessam e que foram provenientes de sua percepção, podendo não necessariamente satisfazer as necessidades dos usuários. Desse modo, para a indexação de xilogravu- 
ras também deve ser considerada a diversidade de significados, interpretações e representações existentes no imaginário e na cultura popular. Portanto, acredita-se que os estudos de usuários, somados às garantias de uso, cultural e ética, podem corroborar para a inclusão da noção de diversidade cultural às práticas de representação dessas imagens, considerando o discurso em que uma comunidade ou grupo objetiva solidificar a sua identidade.

Além disso, faz-se necessário destacar que a complexidade inerente à atividade de indexação de xilogravuras não está apenas associada ao fato da necessidade e compreensão de um conceito contido em recursos não textuais. É importante também que o profissional da informação busque mecanismos para identificar a maneira como os conceitos estão sendo apropriados pelos usuários, uma vez que essas imagens retratam o imaginário e a cultura popular. Com isso, verifica-se a importância da inclusão de uma metodologia colaborativa e integradora que considere os termos que representem efetivamente a literatura e a cultura popular, haja vista que a linguagem é um dos meios pelos quais as ideias são representadas para e por uma cultura.

A xilogravura trata-se de uma rica arte histórica e popular que se apresenta como um mecanismo de propagação de informações através das imagens, com o poder de enriquecer o cenário artístico e cultural através das suas formas de expressão.

Constatou-se no presente estudo que, através dos processos cognitivos, as indexadoras desenvolveram estratégias que viabilizam a atividade de indexação das xilogravuras. $\mathrm{Na}$ oportunidade, as participantes da pesquisa analisaram e identificaram os elementos presentes nas próprias gravuras e os seus respectivos referentes. Porém, em todas as análises efetuadas, como subsídio informacional foram consultados os títulos e os versos dos próprios folhetos cujas xilogravuras estavam sendo representadas. Nessa fase, as participantes tentaram correlacionar o conteúdo da xilogravura com o texto do folheto cuja imagem estava sendo ilustrada, buscando no texto o sentido atribuído à mesma, fazendo analogias que possibilitam a compreensão do sentido dado pelo xilógrafo. No caso das xilogravuras de cordéis, a complementaridade das imagens e das palavras também reside no fato de que se alimentam umas das outras.

Além disso, percebeu-se que para a execução dessa atividade as indexadoras não fizeram uso de metodologias de indexação de recursos imagéticos já existentes na literatura, bem como não utilizaram nenhum instrumento de controle terminológico para a tradução desses termos (como Tesauros, Taxonomias e Ontologias).

Acredita-se que a presente pesquisa atingiu o seu objetivo geral de investigar os aspectos cognitivos inerentes à atividade de indexação de xilogravuras de capas de folhetos de cordel efetuada por bibliotecárias. As xilogravuras de cordéis constituem um rico campo para exploração, principalmente, em relação à sua análise, levando em conta a importância que a xilogravura tem a oferecer para a sociedade, o que justifica a necessidade de um tratamento técnico adequado e específico para a sua organização e recuperação objetivando a disseminação da cultura popular explicitada nessa espécie de material informacional. Desse modo, evidencia-se a necessidade de uma análise bem estruturada e da sistematização de um método para a indexação de xilogravuras, o que se constitui como pesquisa doutoral em andamento realizada por uma das pesquisadoras.

\section{REFERÊNCIAS}

AGUIAR, I. M. et al. Literatura de cordel digitalizada: preservação e disseminação do acervo da Biblioteca Central da Universidade Estadual de Londrina. In: SEMINÁRIO NACIONAL DE 
BIBLIOTECAS UNIVERSITÁRIAS (SNBU), 15., 2008, São Paulo. Anais [...]. São Paulo: UNICAMP, 2008, p.1-8.

ALBUQUERQUE, M. E. B. C. de. Literatura popular de cordel: dos ciclos temáticos à classificação bibliográfica. 2011. Tese (Doutorado em Letras) - Universidade Federal da Paraíba, João Pessoa, 2011.

ARANTES, A.; OKABAYASHI, P. Origens da xilogravura no Nordeste Brasileiro. In: ARANTES, A.; OKABAYASHI, P. A Arte de J. Borges: do cordel a xilogravura. Brasília: Centro Cultural do Banco do Brasil, 2004. p. 39-58.

BARDIN, L. Análise de conteúdo. São Paulo: Edições 70, 2011.

BOTEY, F. E. História del grabado. Madrid: Colección aprendiz-clan Librería editorial, 1997.

BRASIL. Comunicação Para Efeito de Registro do Bem Cultural de Natureza Imaterial Denominado "Literatura de Cordel" Como Patrimônio Cultural do Brasil. Diário Oficial da União. Brasília, DF. 20 ago. 2018. Seção3, p. 12. Disponível em:

https://www.jusbrasil.com.br/diarios/204544074/dou-secao-3-20-08-2018-pg-12 . Acesso em: 27 fev. 2019.

CARVALHO, G. de. A xilogravura de Juazeiro do Norte. Fortaleza: IPHAN, 2014.

CARVALHO, M. F. A representação da mulher em xilogravuras de autoria nordestina. 2015. Tese (Doutorado em Letras) - Centro de Ciências Humanas, Letras e Artes, Universidade Federal da Paraíba, João Pessoa, 2015. Disponível em: http://www.cchla.ufpb.br/ppgl/wpcontent/uploads/2015/04/TESE-DE-MÁRCIA-EM-20.11.2015.pdf. Acesso em: 21 jan. 2019.

COSTELLA, A. F. Breve história ilustrada da xilogravura. Campos do Jordão: Mantiqueira, 2003.

COSTELLA, A. F. Xilogravura: manual prático. São Paulo: Mantiqueira, 1987.

FEBVRE, L.; MARTIN, H-J. O aparecimento do livro. São Paulo: UNESP, 1992.

FRANKLIN, J. Xilogravura popular na literatura de cordel. Brasília: LGE, 2007.

FUJITA, M. S. L. A identificação de conceitos no processo de análise de assunto para indexação. Revista Digital de Biblioteconomia \& Ciência da Informação, Campinas, v. 1, n. 1, p. 60-90, jul./dez. 2003. Disponível em:

http://server01.bc.unicamp.br/revbib/artigos/art_5.pdf. Acesso em: 04 dez. 2018.

FUJITA, M. S. L.; RUBI, M. P. Protocolo Verbal como metodologia sociocognitiva para coleta de dados e recurso pedagógico em sala de aula. In: Marcelino, M. L; Maia, G. Z. A.; Labegalini, A. C. F. B. (Eds.). Pesquisa em educação: passo a passo. Marília: Edições M3T Tecnologia e Educação, 2007. p. 143-154. 
GONÇALVES, E. F.; OLIVEIRA, R. A. de; NEVES, D. A. B. Análise da informação imagética: uma abordagem sob a perspectiva cognitiva. Em Questão, Porto Alegre, v.22, n.3, p.110-135, set./dez. 2016. ISSN 1808-5245. Disponível em:

https://seer.ufrgs.br/EmQuestao/article/view/59905. Acesso em: 04 dez. 2018.

GRANGEIRO, C. R. P. O discurso religioso na literatura de cordel de Juazeiro do Norte. Crato: a Província edições, 2002.

HATA, L. O Cordel das feiras às galerias. 1999. Dissertação (Mestrado em Teoria Literária) Instituto de Estudos da Linguagem, Universidade Estadual de Campinas, São Paulo, 1999. Disponível em: http://www.unicamp.br/iel/memoria/projetos/tese20.html. Acesso em: 21 jan. 2019.

JOLY, M. Introdução à análise de imagem. Campinas, SP: Papirus, 2002.

JORGE, A.; GABRIEL, M. Técnicas da gravura artística. 2.ed. Lisboa: Livros Horizonte, 1986.

LAPLANTINE, F.; TRINDADE, L. O que é imaginário. São Paulo: Brasiliense, 1997. (Coleção Primeiros Passos, 309).

LICARIÃO, V. Xilogravura [Folheto]/V. Licarião. [S.I.:s.n.], [19--]. 8p.

LUCAS, C. R. L. Biblioteconomia: produção e administração da interpretação, Ci. Inf., Brasília, v.26, n.1, p.46-53, jan./abr. 1997. ISSN 1518-8353. Disponível em:

http://www.scielo.br/scielo.php?script=sci arttext\&pid=S0100-19651997000100007. Acesso em: 04 dez. 2018.

MACHADO, R. C. V. J. Borges. Recife, 2003. Disponível em:

http://basilio.fundaj.gov.br/pesquisaescolar/index.php?option=com content\&view=article \& id=394\&/temid=1. Acesso em: 21 jan. 2019.

MACHADO, V. F.; ALBUQUERQUE, A. C. de. A representação temática de xilogravura: o processo de indexação da coleção Paulo Menten. Revista ACB: Biblioteconomia em Santa Catarina, v.21, n.3, p.856-873, ago./nov. 2016. Disponível em:

https://revista.acbsc.org.br/racb/article/view/1253. Acesso em: 04 dez. 2018.

MAIA, M. E.; ALBUQUERQUE, M. E. B. C. O uso da análise da informação nos processos de indexação para o contexto do cordel. Biblios: Revista do Instituto de Ciências Humanas e da Informação. [S.I.], v.28, n.1, p.103-111, jan./jun.2014. Disponível em:

https://periodicos.furg.br/biblos/article/view/3762. Acesso em: 04 dez. 2018.

MAIA, M. E.; AZEVÊDO NETTO, C. X.; OLIVEIRA, B. M. J. F. A experiência nos processos de digitalização do acervo de cordel da Biblioteca Átila de Almeida da Universidade Estadual da Paraíba. Em Questão, Porto Alegre, v.18, n.2, p.85-104, jul./dez. 2012. ISSN 1808-5245. Disponível em: https://seer.ufrgs.br/EmQuestao/article/view/30304. Acesso em: 04 dez. 2018. 
MANINI, M. P. Análise documentária de imagens. Informação \& Sociedade: Estudos, João Pessoa, v. 11, n. 1, p. 1-5, 2002. ISSN 1809-4783. Disponível em:

http://periodicos.ufpb.br/ojs2/index.php/ies. Acesso em: 04 dez. 2018.

MEMÓRIAS DA POESIA POPULAR. Poeta Marcelo Alves Soares: produção literária. 2019. Disponível em: https://memoriasdapoesiapopular.com.br/2014/10/25/poeta-marcelo-alvessoares-producao-literaria/. Acesso em: 20 dez. 2018.

MENEZES, F. C. Xilogravura: o sertão do nosso lugar. Trama interdisciplinar, [S.I.], v.1, n.1, 2010.

MUSSEN, P. H. et al. Desenvolvimento e personalidade da criança. São Paulo: Harbra, 1988.

NAVES, M. N. L. Estudo dos fatores interferentes no processo de análise de assunto. Perspectivas em Ciência da Informação, Belo Horizonte, v. 6, n.2, p.189-203, jul./dez.

2001.Disponível em: http://portaldeperiodicos.eci.ufmg.br/index.php/pci/article/view/428. Acesso em: 04 dez. 2018.

NEVES, D. A. B. Metacognição, informação e conhecimento: pensando em como pensar. Recife: Néctar, 2011.

NEVES, D. A. Ciência da informação e cognição humana: uma abordagem do processamento da informação. Ciência da Informação, Brasília, v. 35, n. 1, p. 39-44, jan./abr. 2006. Disponível em: http://revista.ibict.br/ciinf/article/view/1151/1314. Acesso em: 04 dez. 2018.

NEVES, D. A. B.; DIAS, E. W.; PINHEIRO, A. M. P. O uso de estratégias metacognitivas na leitura do indexador. Ciência da Informação, [S.I.], v.35, n.3, p.141-152, set./dez. 2006. Disponível em: http://revista.ibict.br/ciinf/article/view/1121/1260. Acesso em: 04 dez. 2018.

PANOFSKY, E. Iconografia e iconologia: uma introdução ao estudo da arte da Renascença. In: PANOFSKY, Erwin. Significado nas artes visuais. 3. ed. São Paulo: Perspectiva, 2007.

RIBEIRO, D. O povo brasileiro: a formação e o sentido do Brasil. São Paulo: Companhia das Letras, 2006.

RODRIGUES FILHO, J. A vez e a voz da iconografia: as possibilidades do uso de imagens no campo da Literatura de Cordel. 2016. In: ENCONTRO ESTADUAL DE HISTÓRIA, 17., João Pessoa. Anais [...]. João Pessoa: ANPUH-PB, 2016.

RUBI, M. P. Os princípios da política de indexação na análise de assunto para catalogação: especificidade, exaustividade, revocação e precisão na perspectiva dos catalogadores e usuários. In.: FUJITA, M.S.L., (org.). A indexação de livros: a percepção dos catalogadores e usuários de bibliotecas universitárias. Um estudo de observação do contexto socio cognitivo com protocolos verbais. São Paulo: Editora UNESP; São Paulo: Cultura acadêmica, 2009, p.81-93. 
SANTOS, R. F. Modelos colaborativos de indexação social e a sua aplicabilidade na Base de Dados Referencial de Artigos de Periódicos em Ciência da Informação (BRAPCI). Dissertação (Mestrado em Ciência da Informação) - Universidade Federal de Pernambuco, Recife, 2016. Disponível em:

https://repositorio.ufpe.br/handle/123456789/17218. Acesso em: 04 dez. 2018.

SOUZA, R. V. A xilogravura popular nos projetos de design: um estudo sobre a Compreensão e a utilização das imagens da xilogravura pelos designers. 2007. 138f. Dissertação (Mestrado em Design) - Centro de Artes e Comunicação, Universidade Federal de Pernambuco, Recife, 2007. Disponível em:

https://repositorio.ufpe.br/handle/123456789/3363. Acesso em: 04 dez. 2018. 